Chapter Title: Reccopolitani and Other Town Dwellers in the Southern Meseta during the Visigothic Period of State Formation

Chapter Author(s): Javier Martínez Jiménez

Book Title: Urban Interactions

Book Subtitle: Communication and Competition in Late Antiquity and the Early Middle Ages

Book Editor(s): Michael J. Kelly, Michael Burrows

Published by: Punctum Books. (2020)

Stable URL: https://www.jstor.org/stable/j.ctv19cwdm9.9

JSTOR is a not-for-profit service that helps scholars, researchers, and students discover, use, and build upon a wide range of content in a trusted digital archive. We use information technology and tools to increase productivity and facilitate new forms of scholarship. For more information about JSTOR, please contact support@jstor.org.

Your use of the JSTOR archive indicates your acceptance of the Terms \& Conditions of Use, available at https://about.jstor.org/terms

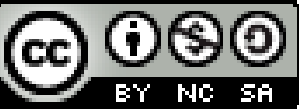

This book is licensed under a Creative Commons Attribution-NonCommercial-ShareAlike 4.0 International License (CC BY-NC-SA 4.0). To view a copy of this license, visit https://creativecommons.org/licenses/by-nc-sa/4.0/.

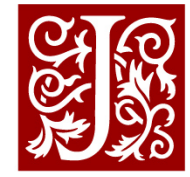

Punctum Books is collaborating with JSTOR to digitize, preserve and extend access to Urban Interactions 


\title{
Reccopolitani and Other Town Dwellers in the Southern Meseta during the Visigothic Period of State Formation
}

\author{
Javier Martínez Jiménez $z^{1}$
}

The ex novo royal urban foundation of Reccopolis, in a largely de-urbanized territory, near the Visigothic capital of Toledo in the late sixth century CE has had a significant impact on how we understand town life in the post-Roman period. This brief analysis of Reccopolis and what we know about its inhabitants (compared and contrasted with what we know of other regional nuclei such as Toledo, El Tolmo, Complutum, or even Mérida) will give an overview of what it may have been like to dwell in an urban site in the core of the Visigothic kingdom during the

1 I would like to thank Michael J. Kelly for inviting me to contribute to this volume and the members of the ERC "The Impact of the Ancient City Project" for their useful comments. This chapter was written while holding a position as a PDRA in the ERC-funded project "The Impact of the Ancient City," directed by Prof. Andrew Wallace-Hadrill. This project has received funding from the European Research Council (ERC) under the European Union's Horizon 2020 research and innovation program (grant agreement no. 693418). 


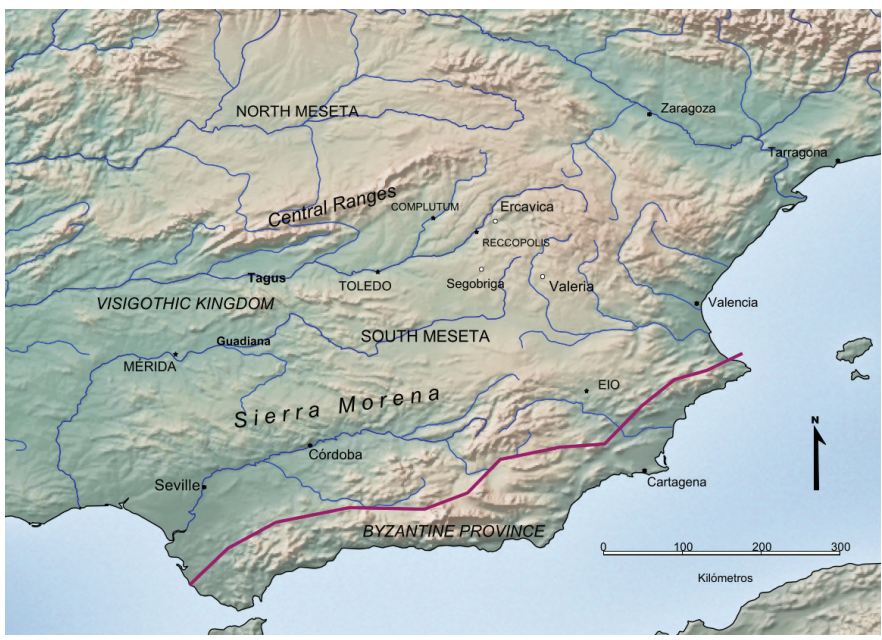

Fig. 1. Map of the southern Meseta, indicating the sites mentioned in the text. Created by the author.

period of state formation, between the late sixth and early seventh centuries.

This paper is in no way a detailed or thorough account on all the archaeological evidence regarding daily urban life. Rather, it presents a series of broad-brush ideas and interpretations based on secondary work (with only a minor proportion resulting from my own field work). First, a synthetic view of five particular cities of the southern Meseta is presented; then, three main issues are approached through the monumental and archaeological remains of these cities. These issues are: first, how these sites were visually and monumentally (both in existing towns and in new foundations); second, a few ideas on what can be inferred regarding daily life (both at the level of the domestic family and the urban community); and third, what can be said about city dwellers and city identities. These are issues which can be framed within the general topic of "urban interactions" in as much as they involve the interactions within the city: the relationships within the urban community, the townscape in 
which it is inscribed, and, to an extent, the interaction between different urban communities.

\section{The Evolution of Townscapes Before the Visigothic Kingdom}

The southern Meseta (fig. 1) is a territory in the Iberian Peninsula located between the Central ranges to the north, the Sierra Morena to the south, the Portuguese lowlands to the west, and the mountainous ranges that separate the flatlands from the Mediterranean coast in the east. It includes the upper and middle valleys of two of the main rivers of the peninsula (the Tagus and the Guadiana), which form fertile, if unnavigable, corridors in what are otherwise dry and nearly barren flat uplands. In the Iron Age, it was largely divided into north-south territories of various "Celt-Iberian" groups. ${ }^{2}$ However, in the Roman period, it was split between the three early Imperial provinces, each of which had a share of this territory, without any clear geographical dividing line. The largest part fell in the Tarraconensis province, and inside the conventus iuridicus (a poorly understood provincial subdivision) ${ }^{3}$ of Cartagena (Carthago Nova). This link to the Mediterranean town was preserved into late antiquity, when it became a separate province: Carthaginensis.

This territory was articulated along three main roads: a road running E-W between Mérida and Valencia; one running NEsw linking Zaragoza with Mérida; and one running NW-SE from the northern Meseta towards Cartagena. This territory was dotted with a small number of minor, secondary towns in

2 The term "Celt-Iberian" is highly controversial. In this instance it is only being used because it was the Roman name given to these groups of Vaccei, Vettones, Carpetani, and others, and not as any sort of ethnic label. Cf. Francisco Burillo Mozota, Los celtíberos. Etnias y estados (Barcelona: Crítica, 1998).

3 Cf. Pablo Ozcariz Gil, Los conventus de la Hispania Citerior (Madrid: Dykinson, 2006). 


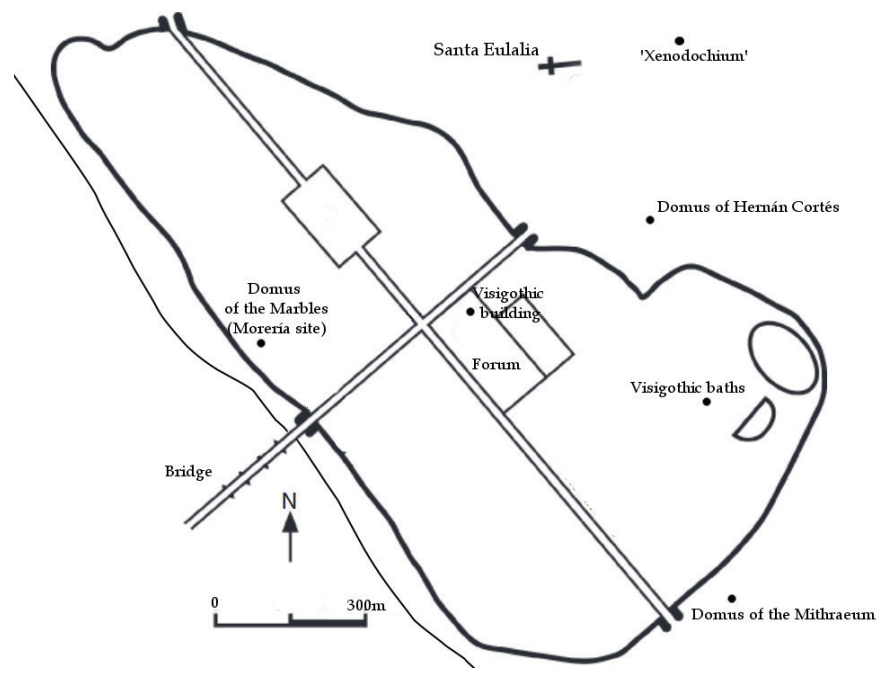

Fig. 2. Plan of Mérida in the Visigothic period. Created by the author.

the Roman period, ${ }^{4}$ which, by late antiquity, and especially after the transformations of the fourth century, ${ }^{5}$ were reduced to a handful of real urban settlements in which town life can be identified. Mérida (the old Roman capital), Toledo (the new Visigothic capital), and Complutum are the best known, together with the new Visigothic foundations of Eio and, our particular case study, Reccopolis. Other sites such as Valeria, Ercavica, or Segobriga are far less known and have not provided us with enough material to discuss their urbanism in the post-Roman period (and in fact, it is very doubtful that they continued to

4 Pieter Houten, Civitates Hispaniae: Urbanisation on the Iberian Peninsula during the High Empire (PhD diss., Leiden University, 2018).

5 Ángel Fuentes Domínguez, "La antigüedad tardía en Castilla-La Mancha," in Castilla-La Mancha en época romana y antigüedad tardía, ed. Ángel Fuentes Domínguez (Ciudad Real: Universidad de Castilla-La Mancha, 2006), 176-213. 
function in any urban way at all), ${ }^{6}$ even if they existed as Visigothic bishoprics.

From these examples (and in fact, from the whole peninsula), Mérida was certainly the most important city (fig. 2). ${ }^{7}$ The former capital of the dioecesis Hispaniarum (which included the Iberian Peninsula and northern Morocco) had a large walled enclosure, reinforced in the fifth century to counter the barbarian threat: its capital role and wealth made it the prime target of the raids of Sueves and Visigoths. The spectacle monuments (theater, amphitheater, circus), which had been renewed during the course of the fourth century with imperial patronage, became the main quarry sites during the fifth and sixth centuries (especially for the construction of the reinforced walled enclosure) and were probably out of use. ${ }^{8}$ The water supply system seems to have been preserved into the late Roman period, but, by the sixth century, it was largely abandoned - despite some failed attempts to put one of the aqueducts back in use. ${ }^{9}$ The fora and other main administrative buildings were similarly quarried and dismantled, although by the temple of the impe-

6 See Adela Cepas Palanca, Crisis y continuidad en la Hispania del siglo III, Anejos de Archivo Español de Arqueología 17 (Madrid: Csic, 1997). On Segóbriga, see Juan Manuel Abascal Palazón, Martín Almagro Gorbea, and Rosario Cebrián Fernández, "Segóbriga visigoda," in Recópolis y la ciudad en la época visigoda, ed. Lauro Olmo Enciso, Zona Arqueológica 9 (Alcalá de Henares: Museo Arqueológico Regional, 2008), 221-41.

7 Other than the chapter in this volume by Pedro Mateos Cruz, see Miguel Alba Calzado, and Pedro Mateos Cruz, "El paisaje urbano de Emerita en época visigoda," in Recópolis y la ciudad en la época visigoda, ed. Olmo Enciso, 261-73.

8 Large clearing excavations early in the twentieth century prevent us from discussing any late antique occupation of these buildings, as it happened in the theater of Cartagena, the amphitheater of Tarragona, or the circus of Arles. The circus of Mérida may have been still in use during the fifth and into the sixth century: Juan Antonio Jiménez Sánchez, "Los últimos ludi circenses realizados en Hispania en época visigoda," Faventia 28, no. 1 (2006): 99-113.

9 Elena Sánchez López and Javier Martínez Jiménez, Los acueductos de Hispania. Construcción y abandono (Madrid: Fundación Juanelo Turriano, 2016), 244-57. 


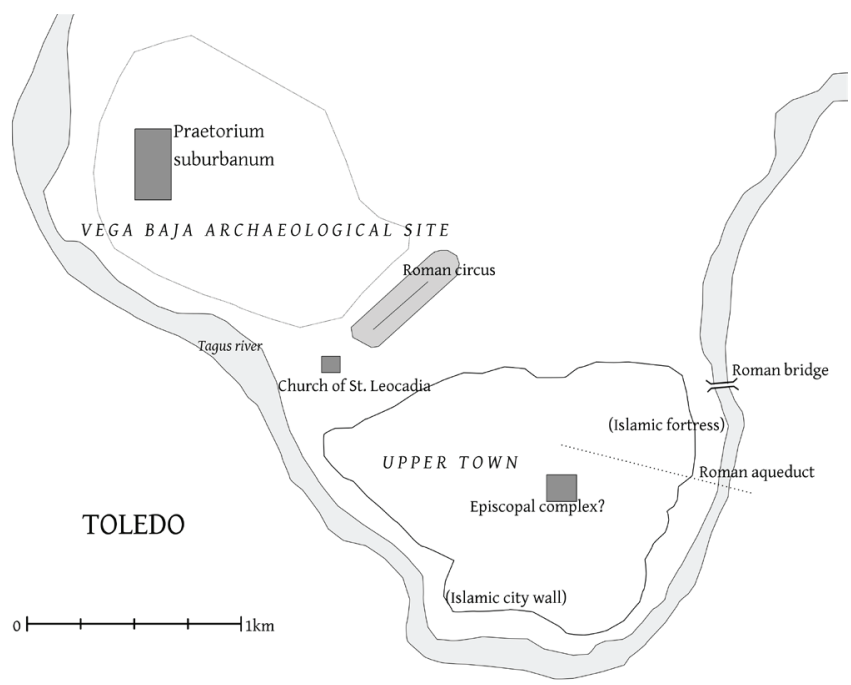

Fig. 3. Plan of late antique Toledo. Created by the author.

rial cult a public(?) building was set up, perhaps linked to the new Visigothic administration of the city. ${ }^{10}$ It was, however, the bishops who were responsible for most of the new constructions of the post-Roman period, including the episcopal complex, the suburban basilica of Saint Eulalia with the "xenodochium," and the repairs of the bridge.

Toledo (fig. 3) had been a secondary town in the Roman administrative system all throughout the Classical period, and it only gained importance during the Visigothic period of state formation when it became the royal capital. The reasons why are not clear, but certainly its central location in the Peninsula (which fitted the new Visigothic policies) and the lack of a strong local aristocracy (as in Mérida, Córdoba, or Zaragoza)

10 Pedro Mateos Cruz and Isaac Sastre de Diego, "Elementos arquitectónicos tardoantiguos y altomedievales en el Templo de Diana (Mérida, España)," Mérida. Excavaciones arqueológicas 7 (2004): 397-415. 
which could contest the royal authority were key. Toledo is, archaeologically, unevenly known: the upper town is still densely inhabited, and there is hardly anything known about its Roman or Visigothic past, other than the street grid and that the cathedral complex was located up there. The walls, allegedly repaired by king Wamba (r. 672-680) were commemorated in an inscription. The lower town (the "Vega Baja"), however, has been subject of much archaeological activity in the recent years. Originally the location of the martyrial basilica of Saint Leocadia, ${ }^{11}$ the circus, and some scattered villa occupation, in the late sixth century the whole area was developed, with a new street grid and the monumental remains of what has been identified with the praetorium suburbanum (the suburban royal palace) mentioned in the sources. ${ }^{12}$

Lastly, it is worth mentioning the old Roman town of Complutum (fig. 4), which offers a point of contrast with these two other flourishing cities of late antiquity. ${ }^{13}$ Complutum had been, like Toledo, a secondary nucleus in the central Meseta, but, from the fourth century onwards, it became an important Christian site thanks to the martyring of two young boys, Saints Justus and Pastor, whose shrine became an important focal point of

Josep Maria Gurt Esparraguera and Pilar Diarte Blasco, "La basílica de santa Leocadia y el final de uso del circo romano de Toledo: Una nueva interpretación," Zephyrus 69 (2012): 149-63.

Lauro Olmo Enciso, "La Vega Baja en época visigoda: una investigación arqueológica en construcción," in La Vega Baja de Toledo, ed. Alfonso García and Diego Perís (Toledo: Toletum Visigodo, 2009), 69-94. Cf. Francisco Moreno Martín, "Circulación de modelos y circularidad de argumentación para el conocimiento de la topografía cristiana entre la Antigüedad Tardía y la Alta Edad Media," in Entre civitas y madina. El mundo de las ciudades en la Península Ibérica y en el norte de África (siglos IV-IX), ed. Sabine Panzram and Laurent Callegarin, Collection de la Casa de Velázquez 167 (Madrid: Casa de Velázquez, 2018), 153-72.

The late antique phases of Complutum are extensively described in Sebastián Rascón Marqués and Ana Lucía Sánchez Montes, "Complutum tardoantiguo," in La investigación arqueológica de la época visigoda en la Comunidad de Madrid, ed. Jorge Morín de Pablos, Zona Arqueológica 8 (Alcalá de Henares: Museo Arqueológico Regional, 2006), 267-91. 


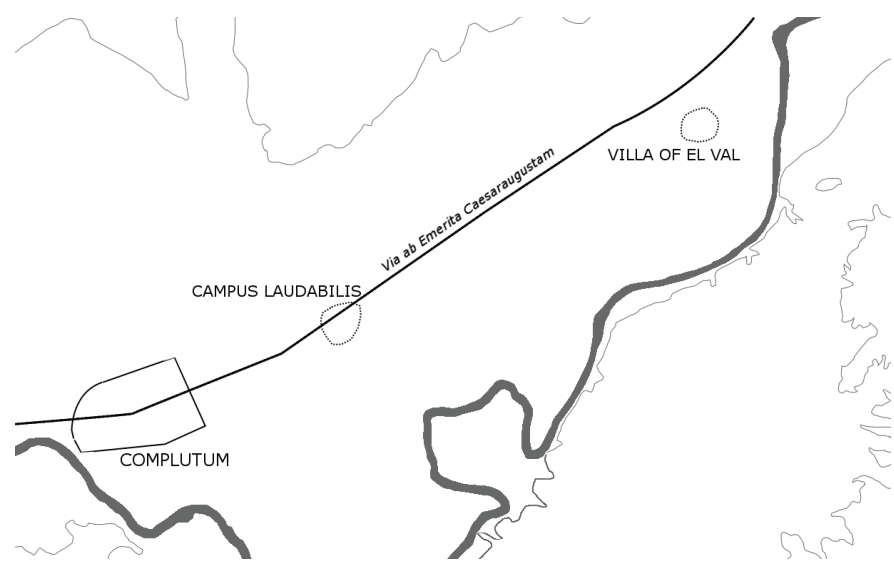

Fig. 4. Plan of the sites mentioned for Complutum in the Visigothic period. Created by the author.

cult activity - comparable to Saint Eulalia. The old walled enclosure, with its forum and administrative center (developed and modified in the fourth century) was largely un-urban by the sixth century. By the period of Visigothic state formation the settlement had spread across three main clusters which completely disregarded the old walls, creating a four-mile dispersed habitat along the main Roman road. The three settlements were around the old villa of El Val, clustered around the Campus Laudabilis (the martyrial shrine of the Holy Boys), and around the forum area.

\section{The New Foundations}

The construction of a new city was a monumental and expensive accomplishment, and a clear statement of state power (and is still nowadays, if we look for instance at the foundations of Canberra in the 1910s, Brasilia in the 1950s, Putrajaya in the 1990 os or Naypyidaw in the 2000s). During late antiquity and the early Middle Ages, city building was an activity which was mostly confined to the Eastern Empire and Sassanid Persia (and 
later taken up by the Umayyads), ${ }^{14}$ but in Visigothic Spain we find two unique examples: Reccopolis and Eio. These two sites are exceptional enough in many aspects not to be taken as characteristic, but they nonetheless reflect the trends and ideals of what a city was conceived to have been.

\section{Reccopolis}

In the case of Reccopolis, all the information we have about the foundation derives from John of Biclar's (c. 540-621) account (later abridged by Isidore of Seville [c. 560-636]), who mentions this: ${ }^{15}$

With the tyrants completely destroyed, and the invaders of Spain defeated, King Liuvigild settled his peace with his own people. He founded a city (civitatem) named after his son in Celtiberia, which he named Reccopolis, which he endowed with wonderful works within the walls and in the suburbs, and he established privileges for the people of the new city (urbis).

We do not know how long the city took to build, or if the date given by John of Biclar of 578 commemorates the beginning of the works or the official inauguration, but the date of 578 coincides with Liuvigild's decennalia, the tenth-year commemoration of his reign (in John of Biclar's computation). Founding a city on such a marked occasion was certainly a great celebration, Rizos, Bibliothèque de l'Antiquité Tardive 35 (Turnhout: Brepols, 2017).

15 Chronica, 578.4: "Liuvigildus rex extinctis undique tyrannis, et pervasoribus Hispaniae superatis sortitus requiem propriam cum plebe resedit civitatem in Celtiberia ex nomine filii condidit, quae $\operatorname{Rec}[\mathrm{c}]$ opolis nuncupatur: quam miro opere et in moenibus et suburbanis adornans privilegia populo novae Urbis instituit." 


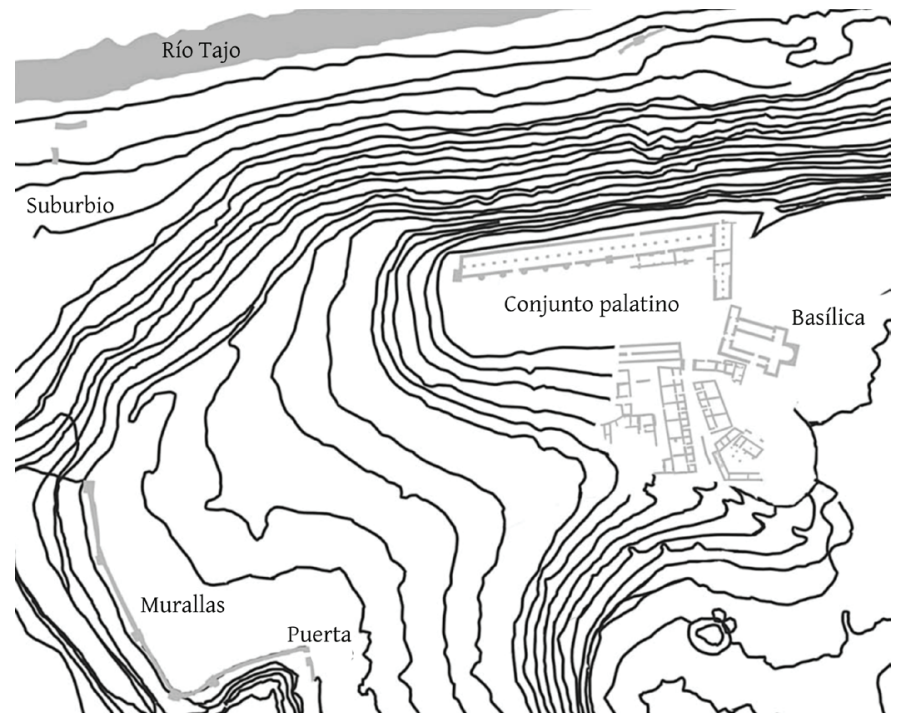

Fig. 5. Plan of the excavations at Reccopolis. Author's original adaptation of an image in Lauro Olmo Enciso, "La ciudad en el centro peninsular durante el proceso de consolidación del estado visigodo de Toledo," Zona arqueológica 8, no. 2 (2006): 251-66, at 255.

and by linking it to Reccared it set the foundations for a dynastic succession. ${ }^{16}$

Regarding the site chosen for the foundation of Reccopolis, it is located on a hilltop adjacent to the River Tagus, sixty-eight miles upstream from Toledo, the royal capital. It is twenty-seven miles $\mathrm{E}$ of Complutum and fourteen miles sw of Ercavica, the two main Roman towns in that area. Even if it is not located on a main Roman road, it was linked with secondary roads. The site had not been previously settled, although the residual presence of fourth-century material may point towards the existence of a less otherwise stated. 
villa in the surrounding area, from which building material was quarried.

If we look at the urbanism of the new city (fig. 5), from John of Biclar we learn that Liuvigild provided it with "splendid buildings" (miro opere), which are not specified. From the archaeology we can guess that these perhaps relate to the basilica and "palatine" complex, located at the upper town. ${ }^{17}$ This area includes an open plaza with an apsed basilica on one end and three long, two-story, aisled buildings on three of the sides. This whole complex was accessed through a monumental gate. These buildings are made of mortared rubble and paved with opus signinum. An aqueduct is also known to have supplied the city, ${ }^{18}$ which may be one of the "splendid buildings," following aqueduct praise in other Gothic royal contexts (in particular, in Ostrogothic Italy). ${ }^{19}$ No other public or monumental buildings are known from the excavations, as most of the site lies in private land and is yet unexcavated, ${ }^{20}$ but if Reccopolis follows other patterns of late antique and post-Roman urbanism, it is

17 All the archaeological descriptions of Reccopolis in this chapter are taken from the extensive list of publications by Lauro Olmo Enciso, from the University of Alcalá de Henares, to whom I am grateful for the opportunities to work with and dig on the site. The key references would be Lauro Olmo Enciso, "Recópolis: una ciudad en época de transformaciones," in Recópolis y la ciudad en la época visigoda, ed. Olmo Enciso, 40-63; Lauro Olmo Enciso, "The Royal Foundation of Recópolis and the Urban Renewal in Iberia During the Second Half of the Sixth Century," in Post-Roman Towns and Trade in Europe and Byzantium, ed. Joachim Henning (Berlin: DeGruyter, 2007), 181-99; and Lauro Olmo Enciso, Manuel Castro Priego, Amaya Gómez de la Torre-Verdejo, and Álvaro Sanz Paratcha, "Recópolis y su justificación científica: la secuencia estratigráfica," in Recópolis y la ciudad en la época visigoda, ed. Olmo Enciso, 64-75.

18 Javier Martínez Jiménez, "A Preliminary Study of the Aqueduct of Reccopolis," Oxford Journal of Archaeology 34, no. 4 (2015): 301-20.

19 Variae, 7.6.2: "In formis autem Romanis utrumque praecipuum est, ut fabrica sit mirabilis et aquarum salubritas singularis" ("Moreover, it is particular to the aqueducts of Rome both [their] wonderful construction and the unique wholesomeness of their waters").

20 Recent geophysical surveys have revealed many other structures, but it is imposible to tell their purpose or function without excavation: Joachim 
doubtful that others will be found. Amphitheaters and theaters were already out of use, as were civil basilicas, but baths were still popular, as the newly built ones of Mérida or Barcelona (although not of the same monumental scale of classical public baths in Spain). ${ }^{21}$ In terms of public amenities, post-Roman town dwellers did not get much else.

Still following John of Biclar's text, Liuvigild also erected walls and built suburbs (which were, as it happens, also privileged with miro opere). The location of the walled enclosure is roughly known, with two gates and various towers identified around the hilltop site. ${ }^{22}$ The suburbs are less well known, although various walls are still visible on the western side of the hilltop, including some by the river bank, which may relate to a river harbor. We could venture that a suburban church existed (the only type of "splendid building" found in other suburbs in Visigothic Spain), but there are no remains to substantiate this. Unless, of course, we count the aqueduct as a suburban building as well.

As for the privileges, it is impossible to know which these were (other than the fact itself of being granted a plot in a new city), but one can guess that these included urban and rural plots of land to settle and to work. Market rights or workshops could have been one of these privileges for which we could have some indirect archaeological evidence. The $\mathrm{N}-\mathrm{s}$ street that leads down from the palace complex towards the main $\mathrm{E}-\mathrm{W}$ road (that linked the two known gates) is flanked by a series of workshops, where glass and gold were worked, and these buildings belong,

Henning et al. "Reccopolis Revealed: First Geomagnetic Mapping of the Early Medieval Visigothic Royal Town," Antiquity 93, no. 369 (2019), 735-51.

Virginia García-Entero, Los balnea domésticos-ámbito rural y urbano-en la Hispania romana. Anejos de Archivo Español de Arqueología 37 (Madrid: CsIC, 2005), 213 (for Barcelona), 527-29 (for Mérida). Note that the date of the bath at Mérida remains unpublished, even if it was excavated recently. I thank Miguel Alba Calzado for pointing this out.

Amaya Gómez de la Torre-Verdejo, "La muralla de Recópolis," in Recópolis y la ciudad en la época visigoda, ed. Olmo Enciso, 77-86. 
stratigraphically, to the same phase as the monuments of the upper town. ${ }^{23}$ If the workshops and the monumental center belong to the same phase, it is logical to deduce that they were built with the same constructive effort, which would further suggest that a way to finance the running of the city might have been by renting out these market areas. This would contrast to the development of the dwelling areas, which belong to a second constructive phase, perhaps up to the initiative of the occupants (which would explain the architectural differences between the houses west and east of the workshop street). There are few other privileges that could be granted to town dwellers, although remission of land taxes was a very popular measure in late and post-Roman legislation; if this measure was granted to cities who had just recovered from war, ${ }^{24}$ it could certainly apply to the inhabitants of a new city before its fields yield their first crops.

From more technical perspectives, and as is evident from the archaeological remains, it is clear that the resources (manpower, financial, and material) necessary to build the city were immense. Doubtless, the largely abandoned Roman town of Ercavica, despite it still being an active bishopric, served as a large quarry - perhaps taking advantage of the fluvial road link between the two sites. All roofs in Reccopolis are tiled, and even if it seems that they were all newly fired imbrices, the large variety of types could also suggest that they were being reused. Marble (not just for decorations, but to be burnt into lime) was probably brought from Ercavica as well, and in large quantities, considering the amount of mortar used at Reccopolis. The burning of the lime and the making of the mortar required large amounts of water, so perhaps the aqueduct was one of the first

23 Olmo Enciso et al., "Recópolis y su justificación”; Manuel Castro Priego and Amaya Gómez de la Torre-Verdejo, "La actividad artesanal en Recópolis: la producción de vidrio," in Recópolis y la ciudad en la época visigoda, ed. Olmo Enciso, 117-28.

24 As, for instance, Marseilles or Arles in the Ostrogothic period (Variae, 3.34, 40 , and 41). 


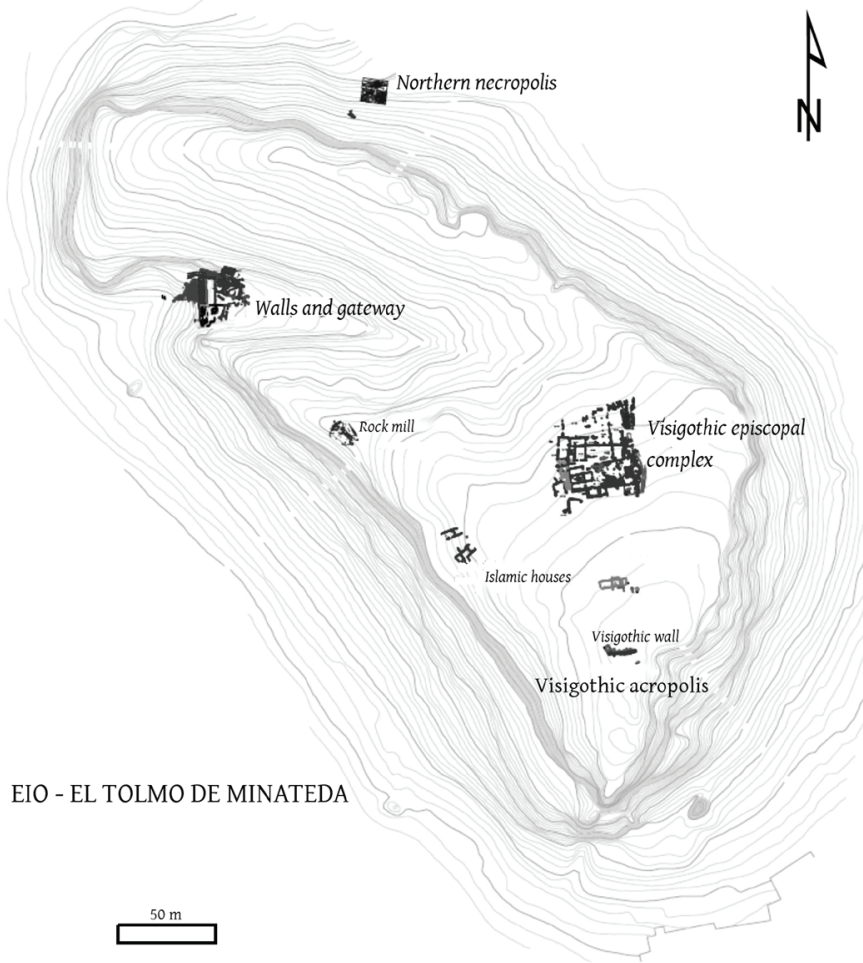

Fig. 6. Plan of the excavations at El Tolmo de Minateda (Eio). Image printed by permission of Sonia Gutiérrez.

structures set up during the construction. Clay and sandstone for ashlars, rubble, and pisé walls could (and can) still be obtained locally around Reccopolis. The presence of a quarry next to the remains of the aqueduct would suggest that this was done on an ad hoc basis, wherever a rocky outcrop was easily accessible, rather than from a large, centralized quarry (a mode of extraction which had disappeared largely by the fifth century). ${ }^{25}$

25 Cf. Anna Gutiérrez García, Roman Quarries in the Northeast of Hispania (Modern Catalonia) (Tarragona: ICAC, 2009), esp. 255-60. 
Regarding the finances, it is clear that the available funds were obtained mostly through confiscations and war booty from Liuvigild's campaigns in the previous years against the Byzantines and various groups of rebels, as described by John of Biclar, but his monetary reform would have also benefitted this project. ${ }^{26}$ As for the manpower, I have suggested elsewhere ${ }^{27}$ that the technical and trained personnel (architects and engineers) required for this project were probably foreign (sent from Byzantium?), but vernacular builders were certainly local. Whether the latter were free or slave, or prisoners of war, is open to discussion, but Liuvigild evidently could muster enough workforce.

Eio

The site of El Tolmo de Minateda (fig. 6), a small rocky outcrop in the mostly plain area that links the southern Meseta with the Mediterranean coast (and the territories controlled by the Byzantines since the mid-sixth century) has been identified with the site of Eio. ${ }^{28}$ This site lacks a source referring to its foundation (as Reccopolis has with John of Biclar), but its existence is inferred from the acts of Visigothic ecclesiastical councils,

26 On Visigothic coinage, see Ruth Pliego Vázquez, La moneda visigoda I. Historia monetaria del Reino visigodo de Toledo (c. 569-711) (Seville: Universidad de Sevilla, 2009).

27 Martínez Jiménez, "Aqueduct of Reccopolis."

28 As with Reccopolis, most of the archaeological information presented here from the excavations at El Tolmo has been extensively published by Sonia Gutiérrez Lloret, from the University of Alicante. The most relevant publications are: Lorenzo Abad Casal, Sonia Gutiérrez Lloret, Blanca Gamo Parras, and Pablo Cánovas Guillén, "Una ciudad en el camino: pasado y futuro de El Tolmo de Minateda (Hellín, Albacete)," in Recópolis y la ciudad en la época visigoda, ed. Olmo Enciso, 323-36; Sonia Gutiérrez Lloret, Lorenzo Abad Casal, and Blanca Gamo Parras, “Eio', 'Iyyuh' y el Tolmo de Minateda (Hellín, Albacete): De sede episcopal a 'madîna' islámica," in VI Reunió d'Arqueologia Cristiana Hispànica, ed. Josep Maria Gurt and Albert Ribera (Barcelona: IEC, 2005), 345-70; and Sonia Gutiérrez Lloret and Julia Sarabia Bautista, "The Episcopal Complex of Eio-El Tolmo de Minateda (Hellín, Albacete, Spain): Architecture and Spatial Organization, 7 th to 8th Centuries AD," Hortus Artium Medeivalium 19 (2013): 267-300. 
where the bishop of Eio or Elo (referred to as Ecclesia Elotana) is listed. The creation of this bishopric was done to counter the power (and claim the territory) of the bishop of Ilici, who was most probably inside the Byzantine province, ${ }^{29}$ and it can be dated to the 590s (a date supported by the archaeology). In this case, as the foundation is not commented on in the sources, all the information derives from the excavations.

From a technical point of view, the construction of Eio is very similar to that of Reccopolis. In terms of resources, Reccared was as successful as his father in his military campaigns, so he had similar access to manpower and cash; additionally, El Tolmo is located on an early Roman urban site (Ilunum), which had been abandoned since the second century, and thus some building materials were reused from this earlier site. In fact, the fortified gate reuses parts of a large imperial dedicatory inscription. Two characteristic elements of the construction of El Tolmo are that mortar is less prominent than in Reccopolis (explaining perhaps the presence of opus africanum) and that the outline of the buildings was chiseled on the bedrock, and then the buildings were erected following those master lines.

Architecturally, the most important monuments at El Tolmo/ Eio are the fortified gate, the episcopal basilica and palace complex, and the fortified acropolis. These elements mirror those of Reccopolis (fortifications, and civil and Church authorities), although in Eio the weight of the ecclesiastical over the civil power reverses the situation of Reccopolis. The episcopal complex at Eio includes a basilica with an apse where the sanctuary is separated with chancel screens, a baptistery, an ad sanctos necropolis, an episcopal hall, and residences, together with a series of rain-water cisterns..$^{30}$ The acropolis consists of a corner of the

29 Javier Martínez Jiménez and José María Moreno Narganes, “Nunc autem a Gothis subversa: The Province of Alicante and the Spanish Mediterranean Towns Between the Byzantine and Visigothic periods," Early Medieval Europe 23 , no. 3 (2015): 263-89.

30 For the cisterns, Javier Martínez Jiménez, "Water Supply in the Visigothic Urban Foundations of Eio (El Tolmo de Minateda) and Reccopolis," in New 
hill, separated from the rest of the site by a wall, and whereas a couple of dwellings have been identified, only the main fortified gate is preserved as a monument on site.

It is conceivable that the settlers for this new site were also granted some privileges (they were moving to the frontier zone with the Byzantines, after all), although it is more difficult to conjecture at what these were than with Reccopolis. The urban nature of the site could be contested on grounds of its size (some seven hectares [17.3 acres]), but the presence of a bishop (evident through the basilica with baptistery) underlines its urban status - even if only from a legal and administrative perspective. It certainly did not inherit much in terms of Roman monumentality from its second-century predecessor: most of the hill was levelled to the bedrock in order to build the new Visigothic settlement.

\section{Daily Life and Domestic Environments}

If compared to Roman imperial foundations (both earlier, Western foundations such as Mérida, Carthage, or Trier, and coeval, Eastern foundations such as Justiniana Prima), the monumental displays of Reccopolis and Eio seem perhaps limited. The lack of colonnaded streets, marble sculptures, amenities such as theaters or baths, or large and lavish basilicas is not just an unfair comparison regarding the substantially different access to resources, but also not really valid, as it does not reflect the underlying social and political circumstances. And this discrepancy between Roman and post-Roman townscapes is not only visible in the monumentality of the cities, but also in their domestic architecture and the objects of daily use, such as pottery. But still, during the post-Roman period there seems to have been an overall similar feel to domestic and daily living in the towns of the central Meseta, both old Roman sites and new Visigothic foundations.

Cities in Late Antiquity, ed. Rizos, 240-41. 


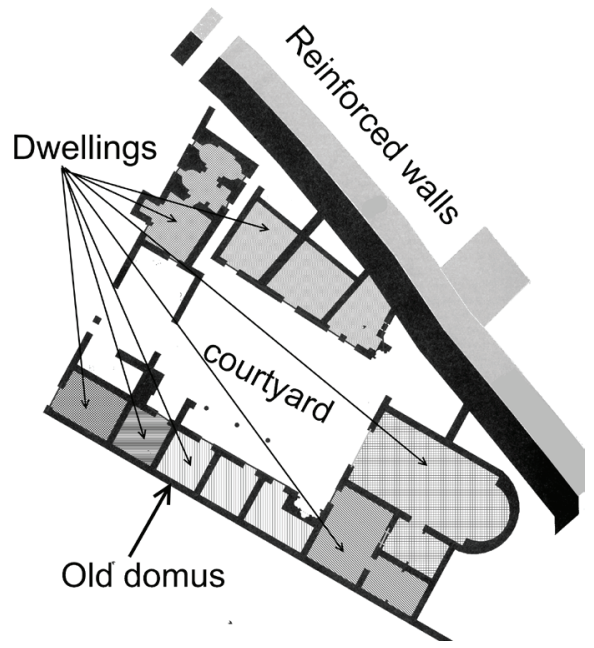

Fig. 7. Plan of the late antique phase domus of the Marbles, excavated at the site of Morería in Mérida. Out of a single-family house of the late Roman period, six different family dwellings are made in the fifth and sixth centuries. Author's original adaption of an image in Miguel Alba Calzado, "La vivienda en Emerita durante la antigüedad tardía: propuesta de un modelo para Hispania," in VI Reunió d'Arqueologia Cristiana Hispànica, ed. Josep Maria Gurt and Albert Ribera (Barcelona: IEC, 2005), 121-50, at 145.

Regarding domestic architecture and houses (the home for the basic unit of social interaction: the family), there is a clear transformation when compared to the Roman world. And in this aspect, the dwelling areas of Reccopolis, Eio, Complutum (late phases of the domus of Hippolytus and of the Cupids), Mérida (Morería site) and Toledo (Vega Baja houses) show very similar characteristics. By the sixth century, urban housing was not linked to atrium-style domus $^{31}$ or even to peristyle or

31 The atrium-style domus, despite being the prototype of Classical Roman housing, existed only during a limited chronology, and was not distributed 
oecus houses; Visigothic urban housing was (as far as archaeology indicates) based around small single-family dwellings (on the premise of one hearth per family unit) with multipurpose rooms (usually no more than two or three linked to the principal room where the hearth is), structured around a courtyard..$^{32}$ In Reccopolis these houses tend to be larger, no doubt because they were built on empty plots for the early settlers, whereas in Mérida (in particular, the dwellings of the Visigothic phase of the domus of the Marbles; fig. 7) they have to fit within the reused rooms of an earlier Roman house. ${ }^{33}$ In this last case, the old peristyle is turned into a communal courtyard. Trampled earth, usually mixed with lime, is the most common flooring technique (perhaps used together with esparto rugs), and the walls were built with pisé on mortared rubble foundations (when not re-using Roman existing walls), and whitewashed.

These houses included rubbish pits and communal water points (cisterns, wells) to counter the lack of aqueduct supplies (in Reccopolis there may have been a public cistern). ${ }^{34}$ Although in Mérida the Roman sewers might have been partially in use, cesspits were also common, but in Reccopolis the idea of vaulted underground sewers is wholly abandoned in favor of open air drains, running in the center of concave streets. ${ }^{35}$ Animal pens,

ubiquitously.

32 For a more theoretical and methodological approach to understanding domestic structures see Sonia Gutiérrez Lloret, "Gramática de la casa. Perspectivas de análisis arqueológico de los espacios domésticos medievales en la Península Ibérica (siglos VII-XIII)," Arqueología de la Arquitectura 9 (2012): 139-64.

33 For Reccopolis, see Olmo Enciso et al., "la secuencia estratigráfica." For Mérida, Miguel Alba Calzado, "La vivienda en Emerita durante la antigüedad tardía: propuesta de un modelo para Hispania," in VI Reunió d’Arqueologia Cristiana Hispànica, ed. Gurt and Ribera, 121-50.

34 Martínez Jiménez, "Aqueduct of Reccopolis."

35 Jesús Acero Pérez and Josep Anton Remolà Vallverdú, La gestión de los residuos urbanos en Hispania. Xavier Dupré Raventós (1956-2006) in memoriam. Anejos de Archivo Español de Arqueología 6o (Mérida: CsIC, 2011). Cf. with the Islamic period: Francisco Vidal Castro, "Agua y urbanismo: evacuación de aguas en fatwà-s de al-Andalus y el Norte de África," in 
small gardens, and other non-residential uses of intra-mural plots have traditionally been seen as indicators of ruralization of the urban landscapes, although for our case studies these appear only in Complutum and the more peripheral areas of Méri$\mathrm{da}$ - these have not been identified in the new foundations.

Non-elite domestic pottery assemblages were modified to fit in these contexts where hearths are on the floor instead of built kitchens, and beaten earth flooring is the most common flooring technique. In this way, characteristic Visigothic coarse wares with thicker walls, clays with mineral inclusions, and convex bases were better adapted to this situation..$^{36}$ The widespread presence of individual bowls and closed shapes in cooking pots would suggest that eating habits had changed: serving individual portions in the bowls rather than sharing dishes on the table with plates and trays. ${ }^{37}$

This simplification of the domestic structure (if compared to Roman urban housing) is only apparent, because none of these houses are elite residences; and in this aspect, lower and middle classes are much more visible in these urban contexts than they

L'urbanisme dans l'occident musulmana u Moyen Âge. Aspects juridiques, ed. Patrice Cressier, Maribel Fierro, and Jean-Pierre van Staëuel (Madrid: Casa Velázquez, 2000), 101-23.

Despite the loss of such techniques as the fast potter's wheel or slips. Cf. Miguel Alba Calzado Miguel and Santiago Feijoo Martínez, "Pautas evolutivas de la cerámica común de Mérida en épocas visigoda y emiral," in Cerámicas tardorromanas y altomedievales en la Península Ibérica, ed. Luis Caballero, Pedro Mateos Cruz, and Manuel Retuerce, Anejos de Archivo Español de Arqueología 28 (Mérida: CsIC, 2003), 483-504.

A thorough study of zooarchaeological, carpological, and archaeobotany remains from urban contexts would give further indications on the nature of urban diets and help to characterize what the urban diet was in the late sixth century; something which exists for rural and urban Islamic contexts: Idoia Grau Sologestoa, The Zooarchaeology of Medieval Álava in its Iberian Context, British Archaeological Reports International Series 2769 (Oxford: Archaeopress, 2015); Marcos García García, "Some Remarks on the Provisioning of Animal Products to Urban Centres in Medieval Islamic Iberia: The Cases of Madinat Ilbirah (Granada) and Cercadilla (Córdoba)," Quaternary International 460 (2016): 86-96. 
are in early Roman towns. This raises the question of where the members of the elite actually lived, episcopal complexes with residences for the clergy and Visigothic palaces apart. Perhaps the houses identified at the Vega Baja in Toledo could be interpreted as residences of the palatine administrative elites, but there is little published about them. Otherwise, late Roman suburban villas in Mérida (like the domus of Hernán Cortés or the domus of the Mithraeum) and Complutum do not continue in use into this period. I would venture that this is a problem of archaeological visibility, and I would expect these elite dwellings close to the new foci of power: episcopal complexes and Visigothic palaces (the environs of which have not been fully excavated for any of the case studies put forward here).

From the nature of these domestic units, organized around communal areas and courtyards, it is possible to guess that beyond the nuclear family, the next level of social interaction took place at a neighborhood level. It is also a possibility that these communities included (but were not limited just to) extended families, a pattern that could perhaps reflect the organization of kin groups in funerary contexts of this period. This hypothesis would link this Visigothic/late antique pattern of social life of a vicus, or neighbor community with later developments in the Islamic period, when this is clearly attested..$^{38}$ This would further link back to Classical Roman practices, where belonging to a vicus was a layer of identity for town dwellers. ${ }^{39}$

Beyond the immediate surroundings, and the interaction within the neighbor community, the wider body of town dwellers had, in the Visigothic period, various places in which to interact with fellow citizens. After the late Roman shift from a curial administration based on magistracies to a local government based on a centrally-appointed count, the forum had

38 Julio Navarro Palazón and Pedro Jiménez Castillo, "Algunas reflexiones sobre el urbanismo islámico," Artigrama 22 (2007): 259-98.

39

Alan Kaiser, Roman Urban Street Networks (London: Routledge, 2011), esp. 38. 
ceased to fulfill a political and administrative role (e.g., for voting, assembling citizens or delivering speeches). ${ }^{40}$ However, this does not imply that open areas were not needed in post-Roman cities. It is true that fora were encroached upon and that their temples, basilicas and decorations were (orderly) dismantled, ${ }^{41}$ but they were still reference landmarks of the city. Even at Reccopolis there was the need for a large open area, even if inside the palatine complex - would the inhabitants have identified it as a forum? I would venture so, even if they just used the word forum simply meaning open urban space, and despite it not being recognizable architecturally as a "Classical" Roman forum..$^{42}$

In the absence of curiae and of classically functioning fora, city dwellers would have gone directly to civil and ecclesiastical palaces (which we know from the archaeology) for their administrative or judicial needs, and our case studies provide various examples of such places. The episcopal complex at Eio has a hall. At Reccopolis it is difficult to envisage how the palace worked (especially considering its layout), ${ }^{43}$ but while the lower ground could have served as a storage for revenue and tax (collected in kind), the upper floor could have held the administrative and audience rooms. The praetorium of Toledo would have had a similar (if not grander) function. In Mérida, other than the obscure Visigothic building of the forum there is the sixth-century

40 Wolfgang Liebeschuetz, "The End of the Ancient City," in The City in Late Antiquity, ed. John Rich (Ashgate: London, 1992), 1-50.

41 Fuentes Domínguez, "La antigüedad tardía," 205-6; Mateos and Sastre, "Elementos arquitectónicos tardoantiguos y altomedievales en el Templo de Diana (Mérida, España);” Rascón and Sánchez, "Complutum tardoantiguo."

42 Or perhaps due to its relationship to the palace, if law was administered there, following cautiously Isidore's definition of a forum (Etym., 15.2.27).

43 And despite the doubts of some scholars, it cannot be denied that the site is Reccopolis and that the upper town is a site of political representation and centralized administration. Cf. Javier Arce, "Recópolis, la ciudad fantasma," in Doctrina a magistro discipulis tradita. Estudios en homenaje al profesor Dr. Luis García Iglesias, ed. Adolfo Domínguez and Gloria Mora Rodríguez (Madrid: Universidad Autónoma de Madrid, 2010), 373-94. 
building north of the city, currently identified with the xenodochium of Masona, a building whose function is not really clear, has a large apsed hall and was decorated with carved marbles, perhaps was used also for holding audiences. ${ }^{44}$

Fora served also as market places in the Roman period. In fact, encroachment could be seen as the permanent occupation of temporary market stalls, so perhaps the presence of a commercial street at Reccopolis can be seen as an indicator that commercial streets were the "market hubs" in late antique towns (as it has been proposed for the East). ${ }^{45}$ Archaeology has yet to shed light on this issue for the case-studies put forward here, because not even in El Tolmo have such structures been found. The eminent local nature of commodities such as glass ${ }^{46}$ and table wares ${ }^{47}$ (as opposed to the abundance of imported wares in the Roman period) may, however, suggest that, as is the case in Reccopolis, production and sales occurred in the same space. This opens two possibilities, which are not necessarily exclusive: production remained largely in the suburbs (so suburbs would be active commercial hubs) or production had partially relocated into the walled enclosures.

Another area where citizen interaction was likely to take place was in religious contexts. It is in this period when church-

44 Pedro Mateos Cruz, "La identificación del xenodochium fundado por Masona en Mérida," in IV Reunió d'Arqueologia Cristiana Hispànica, ed. Josep Maria Gurt Esparraguera and Nuria Tena (Barcelona: Institut d'Estudis Catalans, 1995), 309-16. I have difficulties seeing this building functioning as a hospital.

45 Classically exposed in John Crawford, The Byzantine Shops at Sardis (Cambridge: Harvard University Press, 1990).

46 Ángel Fuentes Domínguez, "Vidrio de la Antigüedad tardía (ss.V-X). Cuestiones de fabricación y comercialización. Problemas de identificación," in Vidrio islámico en Al-Andalus, ed. Enrique Rontomé Notario (Madrid: Fundación Centro Nacional del Vidrio, 2007), 13-36.

47 Alfonso Vigil-Escalera and Juan Antonio Quirós Castillo, eds., La cerámica de la Alta Edad Media en el cuadrante noroeste de la Península Ibérica (siglos $V-X)$ (Bilbao: Universidad del País Vasco, 2016); Caballero, Mateos Cruz, and Retuerce, eds., Cerámicas tardorromanas y altomedievales en la Península Ibérica. 
es begin to be built inside the city walls (Mérida, Toledo), something paralleled by the presence of religious buildings in the centers of the new urban foundations (Reccopolis, Eio). Churches and basilicas in this period had clearly segregated areas for ordained and lay members of the congregation, but they still formed gathering areas for the community - especially on holy days. Masona is known to have carried out processions and making a point out of it during Easter..$^{48}$ Religious processions, well-known in Gallic examples, ${ }^{49}$ may have also existed in Spanish sites at this date..$^{50}$ The presence of both cathedrals and martyrs' shrines in Complutum, Mérida, and Toledo, opens the possibility for such processions linking cathedrals with shrines. In Toledo, king Wamba (slightly after our period) paraded into the city with booty and prisoners (including the usurper Paul) in a style which harks back to Roman triumphs..$^{51}$ The idea may not have been completely foreign, as similar processions existed in the Roman period.

Lastly, it is worth going back to the lack of Roman amenities described earlier. It is true that by the late sixth century none of the Roman spectacula were in use, and they were not set up in the new urban foundations, but the point is that in a Christian urban community where magistrates making payments ex officio did not exist, such forms of entertainment did not have a place. They had become completely outdated, even if horse-racing may have continued into the early sixth century. ${ }^{52}$ Regarding baths, whereas there is general evidence for continuity of bath-

48 Cf. VPE, 5.2.12.

49 Simon Esmonde Cleary, The Roman West, AD 200-500: An Archaeological Study (Cambridge: Cambridge University Press, 2013), 180.

50 One such procession is described for Zaragoza by Gregory of Tours ( $D L H$, 3.29), although not in usual circumstances.

51 HWR, 30. Cf. Hendrik Dey, The Afterlife of the Roman City: Architecture and Ceremony in Late Antiquity and the Early Middle Ages (Cambridge: Cambridge University Press, 2014), 156-57.

52 Jiménez Sánchez, "Los últimos ludi circenses realizados en Hispania en época visigoda.” 
ing, there are few examples of the southern Meseta. ${ }^{53}$ A combination of the ambiguous position of the Church on public bathing and the high costs of maintaining and running large baths (together with the end of aqueduct supplies) meant that these baths were smaller - even with individual tubs, ${ }^{54}$ something that can be seen in the Visigothic baths of Mérida mentioned above. The royal complexes of Toledo and Reccopolis might have had baths, but this is just speculation. The ones known for Complutum were private and certainly out of use by this time. Overall, in terms of public entertainment in these cities there was little on offer that can be seen archaeologically. What other means of post-Roman entertainment city dwellers had is open to interpretation.

\section{Urban Identities?}

If we put together the archaeological information at our disposal, together with the small windows into daily life obtained from the scarce texts (and with a great deal of comparison with other, better studied and more informative areas), it may be possible to have a glimpse of the identities of urban dwellers of our proposed case studies. It should be clearly stated here that by "identity" I am describing a complex series of superimposed and intersecting layers taken by an individual and by communities. Identities are not just social, ethnic or linguistic constructs, but the amalgamation of various characteristics that define an individual within his community and against "the other." ${ }_{55}$

53 Cf. Javier Martínez Jiménez, Aqueducts and Urbanism in post-Roman Hispania, Gorgias Studies in Classical and Late Antiquity 26 (Piscataway: Gorgias Press, 2019).

54 Bryan Ward-Perkins, From Classical Antiquity to the Middle Ages: Urban Public Building in Northern and Central Italy AD 300-850 (Oxford: Oxford University Press, 1984), 152.

55 Walter Pohl, "Introduction: Strategies of Distinction," in Strategies of Distinction: The Construction of Ethnic Communities, 300-80o, ed. Walter Pohl and Helmut Reimitz (Leiden: Brill, 1998), 1-15. 
One clear element of identity that can be pinpointed is that these urban communities were eminently Christian, and there are no archaeological traces of active pagan activity. This may not be surprising or innovative, but it needs saying, even if it is simply because it may be the only element of identity that we can identify with absolute certainty. Besides the biased texts of the Lives of the Father of Mérida (a Christian text about bishops and their deeds), these urban dwellers were building churches, commemorating martyrs' tombs, and burying themselves in Christian fashion and on Christian locations (except for Reccopolis, where the necropolis of Visigothic date is yet to be identified). Even the funerary epigraphy, so abundant in Mérida, is ubiquitous in Christian self-defining epithets such as servus Dei or famulus Dei. ${ }^{66}$ Town dwellers were Christian.

However, one may also point out that at Reccopolis the basilica would have been technically Arian (although liturgically or architectonically there is nothing that distinguishes it from a Catholic/Trinitarian one) as it was founded by Liuvigild, who was a champion of Arianism. Some (if not all?) of the original settlers of Reccopolis might also have been Arians themselves. Liuvigild was trying to achieve unity in his reign, including through the conversion of Catholics into Arianism, Reccopolis might have been a good excuse to have a wholly Arian community. ${ }^{57}$ The re-consecration from Arian to Catholic of the cathedral of Saint Mary in Toledo by Reccared after his conversion, as commemorated in an inscription, ${ }^{58}$ and the reference to

José Luis Ramírez Sádaba, “La primera epigrafía cristiana de Mérida," in Los orígenes del cristianismo en Lusitania, ed. Antonio González and Agustín Velázquez, Cuadernos Emeritenses 34 (Mérida: MNAR, 2008), 101-22. This is all a suggestion, impossible to prove as a working hypothesis.

58 IHC, 155 = ICERV, 302: "In nomine d(o)m(i)n(i) consecra|ta ecclesia S(an) ct(a)e Mari(a)e| in cat(h)olico die pridie| idus aprilis anno feli|citer primo regni d(omi)ni| nostri gloriossisimi Fl(avii)| Reccaredi regis (a)era| DCXXV" ("In the name of the Lord, the church of Saint Mary was consecrated on a Catholic holiday the day before the ides of April in the first joyful year of the reign of our lord most glorious king Flavius Reccared. [Given] in the era of 625 [12 April 587-perhaps Good Friday]"). 
Arian bishops and communities in Lives of the Fathers of Mérida and the acts of church councils also place these religious communities in other main cities of the kingdom. The number and proportion of Arians and Trinitarians is impossible to assess, but these two opposing communities certainly existed. Arianism was also a political marker, as an identity element for the Visigothic ruling elite, and conversions into Arianism would have been ways of climbing up in society.59

A small mention should be made of the Jews, whose presence in the Visigothic kingdom is evident through the constant legislation against them. They are also present in the material record (including a menorah carved in a hermit's cave near Ercavica), but also in inscriptions, such as the funerary epitaph of rabbi Jacob, from late Visigothic Mérida. Judaism would have been an "other" urban identity, as opposed to Christians. ${ }^{60}$

Town dwellers were also Latin-speaking - another obvious observation. However, there were some exceptional examples of Greek-speaking (or Greek-literate) individuals, especially bishops and other minor members of the clergy and occasional traders, recorded both in the sources and evident in the epigraphy. ${ }^{61}$ Regarding Gothic speakers, there is no evidence for or against them, but I think it is doubtful Gothic was much spoken. The Visigoths had been deeply rooted in the Roman system from the end of the fourth century, and by the fifth and sixth they were a very heterogeneous group, with many non-Gothic individuals. Gothic seems to have been used purposefully in the court of Toulouse, but this was incidental and obviously used as a way

59 Manuel Koch, "Arianism and Ethnic Identity in Sixth-century Visigothic Spain," in Arianism: Roman Heresy and Barbarian Creed, ed. Guido Berndt and Roland Steinacher (London: Ashgate, 2014), 257-70.

60 Raúl González Salinero, "Fuentes arqueológicas y documentales para el estudio de los judíos en la Hispania Romana y Visigoda," in ¿Una Sefarad inventada?, ed. Javier Castaño (Córdoba: El Almendro, 2014), 133-6o.

61 Edgar Miguel Cruz, Monteiro Fernandes, and Miguel Filipe Grandão Valerio, "Comunidades helenógrafas en la Lusitania visigoda (s. VI)," Pyrenae 44, no. 2 (2013): 69-108. 
to annoy Roman diplomats. The Arian church seems to have been deeply Latin-based as well, especially if they could conduct theological debates in Latin (in Spain, Gaul, and Africa). The use of personal Gothic names, lastly, is in no way an indicator, as they are simply markers of belonging (or intention to belong to) the Visigothic elite. The limited degree of preservation of Gothic words in Spanish (mostly limited to military terms) would also reinforce this statement.

Regarding ethnicity, ethnic "Romans" (descendants of people who lived in the Peninsula before the fifth century) and ethnic "Goths" (descendants of the Visigoths who settled in Gaul after $418 \mathrm{CE})^{62}$ existed. It is difficult, however, to assess what their sixth-century descendants decided to identify themselves as. In fact, during this period of conflict, the term "Roman" usually depicted the "true Romans," the eastern troops of the "Byzantine" province (although "Goth" and, to a lesser extent, "Roman" still survived to a certain degree as political categories, both eventually simply meaning "citizens of the kingdom"). ${ }^{63}$ It is more likely that at a local and regional level (as it is the case of Gaul as described by Gregory of Tours) ${ }^{64}$ people identified themselves through their extended familia rather than their gens (especially if it was a noble, or senatorial family) and through their city and associated local citizenship. ${ }^{65}$ The fact that there was active competition amongst the main cities at religious and political levels (which city had the most powerful saint, or which city should be

62 The Visigoths were themselves a very heterogeneous group of Gothic and non-Gothic origins; cf. Peter Heather, "Goths and Huns," in Cambridge Ancient History, Volume XIII: The Late Empire, AD 337-425, ed. Averil Cameron and Peter Garnsey (Cambridge: Cambridge University Press, 1998), 487-515.

63 Erica Buchberger, From Romans to Goths and Franks: Ethnic Identities in Sixth- and Seventh-Century Spain and Gaul (Ph.D. diss, University of Oxford, 2012), esp. 80-82. I would like to thank Erica for her comments and for letting me have a look at her thesis.

64 Ibid., 114-17.

65 Javier Martínez Jiménez, "Urban Identity and Citizenship in the West between the Fifth and Seventh Centuries," al-Masaq 32, no. 1 (2020): 81-108. 
the seat of the Visigothic kingdom $)^{66}$ could potentially underline this sense of citizenship or city identity.

The issue of "ethnic identity" is usually complicated when the archaeological record comes into play, especially when scholars (even today) repeatedly go back to old etic interpretative models through which to identify "ethnic" Visigoths through their grave goods. ${ }^{67}$ This problem is, besides, based only on the assumption that the "ethnic Visigothic" community needed to identify and separate itself as such, which is not only a modern idea, but also purely hypothetical. These grave goods (usually weapons and cloisonné jewelry and other metal objects) are perhaps better understood as emic markers of rank and status. ${ }^{68}$ In this way, the grave goods are interpreted not only by themselves, but in their specific (individual grave's skeletal remains) and general (within surrounding burials) contexts. The redefinition of the elites after the collapse of the Roman imperial system and during the process of Visigothic state formation required of an arena in which to display and confirm the new social structure. ${ }^{69}$ These "Germanic" grave goods are linked to members of the new elite in service of the new monarchy, and this elite status is what separates these burials from the largely unfurnished burials of the non-elites. Therefore, weapons and jewelry displayed in

66 Cf. Sabine Panzram, "Mérida contra Toledo, Eulalia contra Leocadia. Listados 'falsificados' de obispos como medio de autorepresentación municipal," in Espacios urbanos en el occidente mediterráneo (S. VI-VIII), ed. Alfonso García (Toledo: Toletum Visigodo, 2010), 123-30.

67 Pots don't equal people: The modern equivalent would be to talk about ethnic "Americans" in Europe through the "iPod culture horizon." Cf. Carlos Tejerizo García, "Ethnicity in Early Middle Age Cemeteries. The Case of the 'Visigothic' Burials," Arqueología y Territorio Medieval 18 (2011): 29-43, who explains this in depth.

68 Cf. Heinrich Härke, “The Nature of Burial Data," in Burials and Society: The Chronological and Social Analysis of Archaeology and Burial Data, ed. Claus Jensen and Karen Nielsen (Aarhus: Aarhus University Press, 1997), 19-29.

69 Guy Halsall, Early Medieval Cemeteries: An Introduction to Burial Archaeology in the Post-Roman West (Skelmorlie: Cruithne Press, 1995), and Guy Halsall, "Ethnicity and Early Medieval Cemeteries," Arqueología y Territorio Medieval 18 (2011): 15-28. 
burials served to reaffirm the position of the deceased's relatives amongst their community as members of the new aristocracy of the kingdom by the conspicuous destruction of wealth (and not necessarily ethnic markers).

That is the theory; the problem arrives when trying to apply this to urban contexts, because most of the necropoleis where these grave goods are found appear in rural contexts. Urban necropoleis tend to be more sober in their funerary display, perhaps because there were other ways of communicating these meanings of rank and status, and perhaps because urban communities were not as small or closed as rural ones. They follow similar patterns of concentration around "central" tombs or sacred spots, with a decreasing presence of metal objects (personal items, vases, etc.) from the sixth into the seventh century, so that by the end of our period the only grave goods appear to be pottery. ${ }^{70}$ As mentioned, there are no burials known for Reccopolis. Near Toledo we find the necropolis of El Carpio de Tajo, with its famous "Visigothic" grave goods, but its location over twenty miles away from Toledo makes it hard to see it as an urban necropolis. If it were an urban necropolis (or linked to inhabitants of Toledo), then the reasons for its distant location are not obvious, and equally intriguing. Mérida, Toledo and Complutum have urban and peri-urban necropoleis, but only the necropolis of Daganzo, near Alcalá de Henares, has any significant finds that could be characterized as "Germanic" (in this case, weapons which simply indicate warrior status)..$^{11}$

70 Cf. Manuel Contreras Martínez and Antonio Fernández Ugalde, “El espacio funerario en el poblado de época visigoda de Gózquez de Arriba (San Martín de la Vega, Madrid)," in La investigación arqueológica de la época visigoda en la Comunidad de Madrid, ed. Jorge Morín de Pablos, Zona Arqueológica 8 (Alcalá de Henares: Museo Arqueológico Regional, 2006), 517-34.

71 Rascón and Sánchez, "Complutum tardoantiguo," 289. 


\section{Conclusions}

When Michael Kulikowski wrote in 2006 "what those sixth- and seventh-century cities looked like, what it felt like to live in them, is at present completely beyond our power to reconstruct," ${ }^{72}$ he certainly highlighted a gap in our knowledge, a gap that perhaps it is nowadays easier to cast light on. In this very generic approach to the archaeology of Reccopolis and other sites from the southern Meseta, I have addressed an overall view of what cities looked like, what cities dwellers might have expected in them, what information we can reconstruct about their daily life, and, more boldly, how they might have portrayed and defined themselves.

In a daring go at a Homeric inversion, let us summarize the main ideas. The big and old question of ethnogenesis and ethnic identity is difficult to see in urban contexts. This is not only because of the lack of characteristic "Germanic" goods in urban sites, but mainly because these items should not be seen as ethnic markers: they are dialectic ways of consolidating rank and status within the community. It is more likely that city dwellers identified themselves through other means, such as family and lineage or, more simply, as members of their civitas and of the kingdom ("Roman" having gone out of fashion long before our period). In this sense, faith and language could have also identified various sub-groups within the body of citizens, which could be antagonized and seen as "the other."

At a more pedestrian level, urban interactions in the late sixth and seventh century took place in the context of Christian monumentality, with some elements that looked back to the Roman past. Most of the public monuments had been set up in a very particular socio-economic system where euergetism and magistracies paying ex officio funded a whole set of new

72 Michael Kulikowski, “The Late Roman City in Spain," in Die Stadt in der Spätantike - Niedergang oder Wandel?, ed. Jens-Uwe Krause and Christian Witschel (Stuttgart: Franz Steiner Verlag, 2006), 143. 
buildings for administration and entertainment. After this very particular mode of funding building and entertainment was displaced by the new, late Roman administration, and partially discredited by the new Christian morals, these buildings ceased to fulfill a function and were slowly dismantled. Reccopolis is very illustrative in this sense, because the constructions identified on the site would reflect the ideal or expected urban amenities in a city of the late sixth century. These include an open area, a commercial street, religious and civil administrative centers and a water supply, but no theater, or circus, or a civil basilica. We have a similar view for Eio - El Tolmo de Minateda. The state and the urban elites had new architectural priorities.

Social gatherings and meeting points in these post-Roman towns would have followed Roman patterns, in as much as fora (in their late Roman modified, partially encroached and/or dismantled version) and market areas. In a few cases, baths also existed, but perhaps Christian buildings, especially in holidays also fulfilled this social function - they were, after all, the spiritual centers of the communities. On occasion, and especially in the royal capital, solemn royal celebrations would have provided entertainment. The layout of Reccopolis could suggest that similar events could have been imagined for it (and even taken place). For more mundane administrative and legal situations, "palaces" offered a centralized point of reference.

In terms of housing, and as far as we can tell from excavations, town dwellers lived in close communities, with more shared spaces than in previous periods as houses themselves became simpler in their design. We know little about the housing of the elites in this period (beyond those from the Vega Baja in Toledo), but this may be a problem of archaeological invisibility. Whether in new housing, in new foundations or in dwellings created out of earlier Roman shells, domestic architecture remains quite similar, with very noticeable changes from earlier or classical phases at all levels. These domestic changes in architecture and design also parallel changes in the domestic wares, which had to increasingly rely on local productions, as imported commodities were no longer available. 
Overall, the inhabitants of Reccopolis had a daily life very similar to other town dwellers of the main cities of the Visigothic kingdom. The common traits shared by those high-status cities with strong economies (state-driven or not) are linked to the continuity of some elements of late Roman town life. In this sense, late Roman and post-Roman cities should be seen as a far more coherently defined as "late antique," in clear contraposition to "Classical" (or rather, "early imperial") examples. The southern Meseta, due to its direct connections with the Visigothic monarchy, could be compared to those important towns in Baetica or the Mediterranean coast, but those towns in the north or the west, where connections with the wider Mediterranean world seem more limited (and where Roman urbanism does not seem to have been as intense or effective), ${ }^{73}$ tell a very different story.

73 Javier Martínez Jiménez and Carlos Tejerizo García, "Central Places in the Post-Roman Mediterranean: Regional Models for the Iberian Peninsula," Journal of Mediterranean Archaeology 28, no. 1 (2015): 81-104. 


\section{Bibliography}

Primary

Chronica $=$ John of Biclar. Chronica a. DLXVII-DXC. Edited by Theodor Mommsen. Monumenta Germaniae Historica, Auctores Antiquissimi 11. Berlin: Weidmann, 1894. $D L H=$ Gregory of Tours. Decem libri historiarum. Edited by Bru-

no Krusch and Wilhelm Levison. Monumenta Germaniae Historica, Scriptores Rerum Merovingicarum 1.1. Hanover: Hahn, 1951.

$H W R=$ Julian of Toledo. Historia Wambae Regis. Edited by Jocelyn N. Hillgarth and and Wilhem Levison. Corpus Christianorum Series Latina 115. Turnhout: Brepols, 1976.

ICERV = Inscripciones cristianas de la España romana y visigoda.

Edited by J. Vives. 2nd Edition. Barcelona: Consejo Superior de Investigaciones Científicas 1969.

IHC $=$ Inscripciones Hispaniae Christianae. Edited by E. Hübner.

Berlin: G. Reimeri, 1871-1900.

Isidore of Seville. Etymologies. Isidori Hispalensis Episcopi Etymologiarum sive Originum Libri XX. Edited by W. M. Lindsay, Oxford, 1911. Translation: The Etymologies of Isidore of Seville. Translated by Stephen A. Barney, W.J. Lewish, J.A. Beach, and Oliver Berghof. Cambridge: Cambridge University Press, 2006.

Variae $=$ Cassiodorus Senator. Epistulae Theodoricanae Variae . Edited by Theodor Mommsen. Monumenta Germaniae Historica, Auctores Antiquissimi 12. Berlin: Weidmann, 1894. VPE $=[$ Paul the Deacon]. De vita Patrum Emeritensium. Edited

by Jacques-Paul Migne. Patrologia Latina 80 (Paris: Garnier, 1863).

\section{Secondary}

Abad Casal, Lorenzo, Sonia Gutiérrez Lloret, Blanca Gamo Parras, and Pablo Cánovas Guillén. "Una ciudad en el camino: pasado y futuro de El Tolmo de Minateda (Hellín, Albacete)." In Recópolis y la ciudad en la época visigoda, edited by Lauro 
Olmo Enciso, 323-36. Zona Arqueológica 9. Alcalá de Henares: Museo Arqueológico Regional, 2008.

Abascal Palazón, Juan Manuel, Martín Almagro Gorbea, and Rosario Cebrián Fernández. "Segóbriga visigoda." In Recópolis y la ciudad en la época visigoda, edited by Lauro Olmo Enciso, 221-41. Zona Arqueológica 9. Alcalá de Henares: Museo Arqueológico Regional, 2008.

Acero Pérez, Jesús, and Josep Anton Remolà Vallverdú. La gestión de los residuos urbanos en Hispania. Xavier Dupré Raventós (1956-2006) in memoriam. Anejos de Archivo Español de Arqueología 6o. Mérida: Csic, 2011.

Alba Calzado, Miguel. "La vivienda en Emerita durante la antigüedad tardía: propuesta de un modelo para Hispania." In VI Reunió d'Arqueologia Cristiana Hispànica, edited by Josep Maria Gurt and Albert Ribera, 121-50. Barcelona: IEC, 2005. Alba Calzado, Miguel, and Pedro Mateos Cruz. "El paisaje urbano de Emerita en época visigoda." In Recópolis y la ciudad en la época visigoda, edited by Lauro Olmo Enciso, 261-73. Zona Arqueológica 9. Alcalá de Henares: Museo Arqueológico Regional, 2008.

Alba Calzado, Miguel, and Santiago Feijoo Martínez. "Pautas evolutivas de la cerámica común de Mérida en épocas visigoda y emiral." In Cerámicas tardorromanas y altomedievales en la Península Ibérica, edited by Luis Caballero, Pedro Mateos, and Manuel Retuerce, 483-504. Anejos de Archivo Español de Arqueología 28. Mérida: CSIC, 2003.

Arce, Javier. “Recópolis, la ciudad fantasma." In Doctrina a magistro discipulis tradita. Estudios en homenaje al profesor Dr. Luis García Iglesias, edited by Adolfo Domínguez and Gloria Mora Rodríguez, 373-94. Madrid: Universidad Autónoma de Madrid, 2010.

Buchberger, Erica. From Romans to Goths and Franks: Ethnic Identities in Sixth-and Seventh-Century Spain and Gaul. Ph.D. diss., University of Oxford, 2012. https://ora.ox.ac.uk/ objects/uuid:1c7oa75a-9556-4642-93ea-22ob877155c6.

Burillo Mozota, Francisco. Los celtíberos. Etnias y estados. Barcelona: Crítica, 1998. 
Caballero Zoreda, Luis, Pedro Mateos Cruz, and Manuel Retuerce, eds. Cerámicas tardorromanas y altomedievales en la Península Ibérica. Anejos de Archivo Español de Arqueología 28. Mérida: CSIC, 2003.

Castro Priego, Manuel, and Amaya Gómez de la Torre-Verdejo. "La actividad artesanal en Recópolis: la producción de vidrio." In Recópolis y la ciudad en la época visigoda, edited by Lauro Olmo Enciso, 117-28. Zona Arqueológica 9. Alcalá de Henares: Museo Arqueológico Regional, 2008.

Cepas Palanca, Adela. Crisis y continuidad en la Hispania del siglo III. Anejos de Archivo Español de Arqueología 17. Madrid: CSIC, 1997.

Contreras Martínez, Manuel, and Antonio Fernández Ugalde. "El espacio funerario en el poblado de época visigoda de Gózquez de Arriba (San Martín de la Vega, Madrid)." In La investigación arqueológica de la época visigoda en la Comunidad de Madrid, edited by Jorge Morín de Pablos, 517-34. Zona Arqueológica 8. Alcalá de Henares: Museo Arqueológico Regional, 2006.

Crawford, John. The Byzantine Shops at Sardis. Cambridge: Harvard University Press, 1990.

Dey, Hendrik. The Afterlife of the Roman City: Architecture and Ceremony in Late Antiquity and the Early Middle Ages. Cambridge: Cambridge University Press, 2014. DoI: 10.1017/ CBO9781107706538.

Esmonde Cleary, Simon. The Roman West, AD 200-50o: An Archaeological Study. Cambridge: Cambridge University Press, 2013. DOI: 10.1017/CBO9781139043199.

Fernandes, Edgar Miguel Cruz Monteiro, and Miguel Filipe Grandão Valerio. "Comunidades helenógrafas en la Lusitania visigoda (s. VI)." Pyrenae 44, no. 2 (2013): 69-108.

Fuentes Domínguez, Ángel. "La antigüedad tardía en CastillaLa Mancha." In Castilla-La Mancha en época romana y antigüedad tardía, edited by Ángel Fuentes Domínguez, 176-213. Ciudad Real: Universidad de Castilla-La Mancha, 2006. . "Vidrio de la Antigüedad tardía (ss.V-X). Cuestiones de fabricación y comercialización. Problemas de identifi- 
cación." In Vidrio islámico en Al-Andalus, edited by Enrique Rontomé Notario, 13-36. Madrid: Fundación Centro Nacional del Vidrio, 2007.

García García, Marcos. "Some Remarks on the Provisioning of Animal Products to Urban Centres in Medieval Islamic Iberia: The Cases of Madinat Ilbirah (Granada) and Cercadilla (Cordoba)." Quaternary International 460 (2016): 86-96. DOI: 10.1016/j.quaint.2016.06.021.

García-Entero, Virginia. Los balnea domésticos - ámbito rural y urbano - en la Hispania romana. Anejos de Archivo Español de Arqueología 37. Madrid: CSIC, 2005.

Gómez de la Torre-Verdejo, Amaya. "La muralla de Recópolis." In Recópolis y la ciudad en la época visigoda, edited by Lauro Olmo Enciso, 77-86. Zona Arqueológica 9. Alcalá de Henares: Museo Arqueológico Regional, 2008.

González Salinero, Raúl. "Fuentes arqueológicas y documentales para el estudio de los judíos en la Hispania Romana y Visigoda." In ¿Una Sefarad inventada?, edited by Javier Castaño, 133-6o. Córdoba: El Almendro, 2014.

Grau Sologestoa, Idoia. The Zooarchaeology of Medieval Álava in its Iberian Context. British Archaeological Reports International Series 2769. Oxford: Archaeopress, 2015.

Gurt Esparraguera, Josep Maria, and Pilar Diarte Blasco. "La basílica de santa Leocadia y el final de uso del circo romano de Toledo: Una nueva interpretación." Zephyrus 69 (2012): 149-63.

Gutiérrez García, Anna. Roman Quarries in the Northeast of Hispania (Modern Catalonia). Tarragona: ICAC, 2009.

Gutiérrez Lloret, Sonia. “Gramática de la casa. Perspectivas de análisis arqueológico de los espacios domésticos medievales en la Península Ibérica (siglos VII-XIII).” Arqueología de la Arquitectura 9 (2012): 139-64. DOI: 10.3989/arqarqt.2012.11602.

Gutiérrez Lloret, Sonia, Lorenzo Abad Casal, and Blanca Gamo Parras. "Eio,' 'Iyyuh' y el Tolmo de Minateda (Hellín, Albacete): de sede episcopal a 'madîna' islámica." In VI Reunió 
d'Arqueologia Cristiana Hispànica, edited by Josep Maria Gurt and Albert Ribera, 345-70. Barcelona: IEC, 2005.

Gutiérrez Lloret, Sonia, and Julia Sarabia Bautista. "The Episcopal Complex of Eio-El Tolmo de Minateda (Hellín, Albacete, Spain). Architecture and Spatial Organization. 7 th to 8th Centuries AD." Hortus Artium Medeivalium 19 (2013): 267300. DOI: 10.1484/J.HAM.1.103584.

Härke, Heinrich. "The Nature of Burial Data." In Burials and Society: The Chronological and Social Analysis of Archaeology and Burial Data, edited by Claus Jensen and Karen Nielsen, 19-29. Aarhus: Aarhus University Press, 1997.

Halsall, Guy. Early Medieval Cemeteries: An Introduction to Burial Archaeology in the Post-Roman West. Skelmorlie: Cruithne Press, 1995.

- "Ethnicity and Early Medieval Cemeteries." Arqueología y Territorio Medieval 18 (2011): 15-28.

Heather, Peter. "Goths and Huns." In Cambridge Ancient History. Volume XIII. The Late Empire, AD 337-425, edited by Averil Cameron and Peter Garnsey, 487-515. Cambridge: Cambridge University Press, 1998. DoI: 10.1017/ CHOL9780521302005.017.

Henning, Joachim, Michael McCormick, Lauro Olmo Enciso, Knut Rassman, and Eyub Fikrit. "Reccopolis Revealed: First Geomagnetic Mapping of the Early Medieval Visigothic Royal Town," Antiquity 93, no. 369 (2019), 735-51. DOI: 10.15184/ aqy.2019.66.

Houten, Pieter. Civitates Hispaniae: Urbanisation on the Iberian Peninsula during the High Empire. Ph.D. diss., Leiden University, 2018. https://openaccess.leidenuniv.nl/handle/1887/68032.

Jiménez Sánchez, Juan Anotnio. "Los últimos ludi circenses realizados en Hispania en época visigoda.” Faventia 28, no. 1 (2006): 99-113.

Kaiser, Alan. Roman Urban Street Networks. London: Routledge, 2011. DOI: $10.4324 / 9780203821817$.

Koch, Manuel. "Arianism and Ethnic Identity in Sixth-century Visigothic Spain." In Arianism: Roman Heresy and Barbar- 
ian Creed, edited by Guido Berndt and Roland Steinacher, 257-70. London: Ashgate, 2014.

Kulikowski, Michael. “The Late Roman City in Spain.” In Die Stadt in der Spätantike - Niedergang oder Wandel?, edited by Jens-Uwe Krause and Christian Witschel, 129-49. Stuttgart: Franz Steiner Verlag, 2006.

Liebeschuetz, Wolfgang. "The End of the Ancient City." In The City in Late Antiquity, edited by John Rich, 1-50. Ashgate: London, 1992.

Martínez Jiménez, Javier. "A Preliminary Study of the Aqueduct of Reccopolis." Oxford Journal of Archaeology 34, no. 4 (2015): 301-20. DOI: 10.1111/ojoa.12060.

. Aqueducts and Urbanism in post-Roman Hispania. Gorgias Studies in Classical and Late Antiquity 26. Piscataway: Gorgias Press, 2019.

. "Urban Identity and Citizenship in the West between the Fifth and Seventh Centuries." al-Masaq 32, no. 1 (2020): 81-108. DOI: 10.1080/09503110.2019.1675026.

. "Water Supply in the Visigothic Urban Foundations of Eio (El Tolmo de Minateda) and Reccopolis." In New Cities in Late Antiquity: Documents and Archaeology, edited by Efthymios Rizos, 233-45. Bibliothèque de l'Antiquité Tardive 35. Turnhout: Brepols, 2017.

Martínez Jiménez, Javier, and Carlos Tejerizo García. "Central Places in the Post-Roman Mediterranean: Regional Models for the Iberian Peninsula." Journal of Mediterranean Archaeology 28, no. 1 (2015): 81-104. DOI: 10.1558/jmea.v28i1.27502.

Martínez Jiménez, Javier, and José María Moreno Narganes. "Nunc autem a Gothis subversa: The Province of Alicante and the Spanish Mediterranean Towns Between the Byzantine and Visigothic Periods." Early Medieval Europe 23, no. 3 (2015): 263-89. DoI: 10.1111/emed.12104

Mateos Cruz, Pedro. "La identificación del xenodochium fundado por Masona en Mérida." In IV Reunió d'Arqueologia Cristiana Hispànica, edited by Josep Maria Gurt Esparraguera, and Núria Tena, 309-16. Barcelona: Institut d'Estudis Catalans, 1995. 
Mateos Cruz, Pedro, and Isaac Sastre de Diego. "Elementos arquitectónicos tardoantiguos y altomedievales en el Templo de Diana (Mérida, España)." Mérida. Excavaciones arqueológicas 7 (2004): 397-415.

Moreno Martín, Francisco. "Circulación de modelos y circularidad de argumentación para el conocimiento de la topografía cristiana entre la Antigüedad Tardía y la Alta Edad Media," In Entre civitas y madina. El mundo de las ciudades en la Península Ibérica y en el norte de África (siglos IV-IX), edited by Sabine Panzram and Laurent Callegarin, 153-72. Collection de la Casa de Velázquez 16. Madrid: Casa de Velázquez, 2018. Navarro Palazón, Julio, and Pedro Jiménez Castillo. "Algunas reflexiones sobre el urbanismo islámico." Artigrama 22 (2007): $259-98$

Olmo Enciso, Lauro. "La Vega Baja en época visigoda: una investigación arqueológica en construcción." In La Vega Baja de Toledo, edited by Alfonso García and Diego Perís, 69-94. Toledo: Toletum Visigodo, 2009.

- "Recópolis: una ciudad en época de transformaciones." In Recópolis y la ciudad en la época visigoda, edited by Lauro Olmo Enciso, 40-63. Zona Arqueológica 9. Alcalá de Henares: Museo Arqueológico Regional, 2008.

. "The Royal Foundation of Recópolis and the Urban Renewal in Iberia during the Second Half of the Sixth Century." In Post-Roman Towns and Trade in Europe and Byzantium, edited by Joachim Henning, 181-99. Berlin: DeGruyter, 2007.

Olmo Enciso, Lauro, Manuel Castro Priego, Amaya Gómez de la Torre-Verdejo, and Álvaro Sanz Paratcha. "Recópolis y su justificación científica: la secuencia estratigráfica.” In Recópolis y la ciudad en la época visigoda, edited by Lauro Olmo Enciso, 64-75. Zona Arqueológica 9. Alcalá de Henares: Museo Arqueológico Regional, 2008.

Ozcariz Gil, Pablo. Los conventus de la Hispania Citerior. Madrid: Dykinson, 2006.

Panzram, Sabine. "Mérida contra Toledo, Eulalia contra Leocadia. Listados 'falsificados' de obispos como medio de autorepresentación municipal." In Espacios urbanos en el occi- 
dente mediterráneo (S. VI-VIII), edited by Alfonso García, 123-30. Toledo: Toletum Visigodo, 2010.

Pliego Vázquez, Ruth. La moneda visigoda I. Historia monetaria del Reino visigodo de Toledo (c. 569-711). Seville: Universidad de Sevilla, 2009.

Pohl, Walter. "Introduction: Strategies of Distinction." In Strategies of Distinction: The Construction of Ethnic Communities, 300-800, edited by Walter Pohl and Helmut Reimitz, 1-15. Leiden: Brill, 1998.

Ramírez Sádaba, José Luis. "La primera epigrafía cristiana de Mérida." In Los orígenes del cristianismo en Lusitania, edited by Antonio González and Agustín Velázquez, 101-22. Cuadernos Emeritenses 34. Mérida: MNAR, 2008.

Rascón Marqués, Sebastián, and Ana Lucía Sánchez Montes. “Complutum tardoantiguo." In La investigación arqueológica de la época visigoda en la Comunidad de Madrid, edited by Jorge Morín de Pablos, 267-91. Zona Arqueológica 8. Alcalá de Henares: Museo Arqueológico Regional, 2006.

Rizos, Efthymios, ed. New Cities in Late Antiquity. Documents and Archaeology. Bibliothèque de l'Antiquité Tardive 35 . Turnhout: Brepols, 2017.

Sánchez López, Elena, and Javier Martínez Jiménez. Los Acueductos de Hispania. Construcción y Abandono. Madrid: Fundación Juanelo Turriano, 2016.

Tejerizo García, Carlos. "Ethnicity in Early Middle Age Cemeteries. The Case of the 'Visigothic' Burials." Arqueología y Territorio Medieval 18 (2011): 29-43.

Vidal Castro, Francisco. "Agua y urbanismo: evacuación de aguas en fatwà-s de al-Andalus y el Norte de África." In Lurbanisme dans l'occident musulmana du Moyen Âge. Aspects juridiques, edited by Patrice Cressier, Maribel Fierro, and Jean-Pierre van Staëuel, 101-23. Madrid: Casa Velázquez, 2000.

Vigil-Escalera, Alfonso, and Juan Antonio Quirós Castillo, eds. La cerámica de la Alta Edad Media en el cuadrante noroeste de la Península Ibérica (siglos $V-X$ ). Bilbao: Universidad del País Vasco, 2016. 


\section{URBAN INTERACTIONS}

Ward-Perkins, Bryan. From Classical Antiquity to the Middle Ages: Urban Public Building in Northern and Central Italy $A D$ 300-850. Oxford: Oxford University Press, 1984. 